\title{
MODUL VIRTUAL: MULTIMEDIA FLIPBOOK DASAR TEKNIK DIGITAL
}

\author{
Dony Sugianto, Ade Gafar Abdullah, Siscka Elvyanti, Yuda Muladi \\ Program Studi Pendidikan Teknik Elektro \\ Fakultas Pendidikan Teknologi dan Kejuruan \\ Universitas Pendidikan Indonesia \\ Jl. Dr. Setiabudhi 207 Bandung \\ Email : dony.sugianto@yahoo.com
}

\begin{abstract}
Abstrak. Perkembangan teknologi informasi dan komunikasi, berpengaruh juga terhadap kemajuan inovasi media pembelajaran. Makalah ini mengeksplorasi hasil perencanaan, pembuatan dan implementasi modul virtual pembelajaran dasar teknik digital. Tujuannya adalah untuk menguji validitas produk sehingga memenuhi kelayakan sebagai media pembelajaran. Prosedur penelitian dilakukan melalui langkah-langkah penelitian pengembangan, dengan metode evaluatif. Hasil penelitian membuktikan bahwa modul virtual ini memiliki tampilan yang menarik, mudah dipahami dan mudah digunakan. Diharapkan hasil pengembangan modul virtual ini berdampak terhadap peningkatan penguasaan peserta didik dalam mempelajari dasar teknik digital.
\end{abstract}

Kata Kunci : kvisoft flipbook maker, modul virtual, multimedia flipbook, teknik digital.

\begin{abstract}
The development of information and communication technology effects innovations in learning media. This article discusses the planning and making as well as the implementation of virtual module in digital technique basic learning. The research examined product validity and feasibility as a learning medium. Research procedure was conducted through development research, employing evaluative method. This article shows that the virtual module has an attractive appearance, so that it is easy to understand and to apply. It is expected that the development of this virtual module will improve students' mastery in basic digital technique.
\end{abstract}

Keywords: kvisoft flipbook maker, virtual module, multimedia flipbook, digital technique.

\section{PENDAHULUAN}

Teknologi multimedia telah menjanjikan potensi besar dalam merubah cara seseorang untuk belajar, untuk memperoleh informasi, menyesuaikan informasi dan sebagainya. Multimedia juga menyediakan peluang bagi pendidik untuk mengembangkan teknik pembelajaran sehingga menghasilkan hasil yang maksimal. Demikian juga bagi peserta didik, dengan multimedia diharapkan mereka akan lebih mudah untuk menentukan dengan apa dan bagaimana dapat menyerap informasi secara cepat dan efisien. Oleh karena itu, kehadiran multimedia dalam proses belajar menjadi sangat bermanfaat. 
Salah satu media pembelajaran yang diharapkan dapat menciptakan suasana belajar yang menarik dan kondusif yaitu dengan penggunaan multimedia Flipbook. Dengan menggunakan media pembelajaran tersebut diharapkan dapat memberikan pembaharuan dalam proses pembelajaran di kelas. Penggunaan media Flash Flipbook dapat menambah motivasi belajar peserta didik dan juga dapat mempengaruhi prestasi atau hasil belajar peserta didik (Ramdania, 2013). Penggunaan Flipbook juga dapat meningkatkan pemahaman dan meningkatkan pencapaian hasil belajar (Nazeri, 2013).

Media pembelajaran mempunyai dua komponen, yaitu hardware dan software serta mempunyai bentuk-bentuk baik teks, audio, visual, gambar, dan animasi sehingga dapat merangsang pikiran, perasaan, perhatian, dan minat serta perhatian siswa sedemikian rupa sehingga proses belajar terjadi. Untuk mengembangkan media pembelajaran perlu diperhatikan prinsip VISUALS, yang dapat digambarkan sebagai singkatan dari kata-kata: Visible: mudah dilihat, Interesting: menarik, Simple: sederhana, Useful: isinya berguna/bermanfaat, Accurate: Benar (dapat dipertanggungjawabkan), Legitimate: masuk akal/sah, Structured: terstruktur/tersusun dengan baik. (Nurseto, 2011).

Perkembangan teknologi e-book mendorong terjadinya perpaduan antara teknologi cetak dengan teknologi komputer dalam kegiaan pembelajaran, salah satunya yaitu modul. Modul dapat ditransformasikan penyajiannya ke dalam bentuk elektronik sehingga diberi istilah modul elektronik atau modul virtual. Modul elektronik adalah sebuah bentuk penyajian bahan belajar mandiri yang disusun secara sistematis ke dalam unit pembelajaran terkecil untuk mencapai tujuan pembelajaran tertentu yang disajikan ke dalam format elektronik yang di dalamnya terdapat animasi, audio, navigasi yang membuat pengguna lebih interaktif dengan program. Dengan adanya modul elektronik yang bersifat interaktif ini proses pembelajaran akan melibatkan tampilan audio visual, sound, movie dan yang lainnya serta program tersebut pemakaiannya mudah dipahami sehingga dapat dijadikan media pembelajaran yang baik (Gunawan, 2010).

Modul elektronik dapat diimplementasikan sebagai sumber belajar mandiri yang dapat membantu siswa dalam meningkatkan kompetensi atau pemahaman 
secara kognitif yang dimilikinya serta tidak bergantung lagi pada satu-satunya sumber informasi. Modul elektronik juga dapat digunakan dimana saja, sehingga lebih praktis untuk dibawa kemana saja. Karena merupakan penggabungan dari media cetak dan komputer, maka modul elektronik dapat menyajikan informasi secara terstruktur, menarik serta memiliki tingkat interaktifitas yang tinggi. Selain itu, proses pembelajaran tidak lagi bergantung pada instruktur sebagai satusatunya sumber informasi (Gunadharma, 2011). Modul elektronik juga dapat digunakan untuk meningkatkan pemahaman konsep dari materi yang disampaikan pendidik (Wahyuni, 2013).

Multimedia merupakan perpaduan antara berbagai media (format file) yang berupa teks, gambar, grafik, musik, animasi, video, interaksi dan lain-lain, yang telah dikemas menjadi file digital (komputerisasi), serta digunkan untuk menyampaikan pesan kepada pengguna. Sedangkan interaktif berkaitan dengan proses komunikasi dua arah atau lebih dari komponen-komponen komunikasi. Komponen komunikasi dalam multimedia interaktif adalah hubungan antara manusia sebagai user/pengguna dengan komputer sebagai alat yang memberikan informasi.

Pembuatan media pembelajaran berbasis multimedia dilakukan dengan menggunakan perangkat lunak/software yang bersifat open source. Perangkat lunak tersebut adalah Kvisoft Flipbook Marker yang merupakan perangkat lunak/software yang digunakan untuk membuat tampilan buku atau bahan ajar lainnya menjadi sebuah buku elektronik digital berbentuk flipbook. Perangkat lunak tersebut dapat diunduh secara bebas atau gratis melalui akses internet.

Kvisoft Flipbook Maker adalah perangkat lunak yang handal yang dirancang untuk mengkonversi file PDF ke halaman-balik publikasi digital. Software ini dapat mengubah tampilan file PDF menjadi lebih menarik seperti layaknya sebuah buku. Tidak hanya itu, Kvisoft Flipbook Maker juga dapat membuat file PDF menjadi seperti sebuah majalah, Majalah Digital, Flipbook, Katalog Perusahaan, Katalog digital dan lain-lain. Dengan menggunakan perangkat lunak tersebut, tampilan media akan lebih variatif, tidak hanya teks, 
gambar, video, dan audio juga bisa disisipkan dalam media ini sehingga proses pembelajaran akan lebih menarik (Ramdania, 2013).

Pada Kvisoft Flipbook Maker kita dapat menambahkan file-file gambar, pdf, swf, dan file video berformat FLV dan MP4. Sedangkan keluaran atau output dari software ini dapat berupa HTML, EXE, ZIP, dan APP. Output TI Flash membalik buku sebagai format HTML yang memungkinkan kalian untuk mengupload ke website untuk dilihat secara online. Output sebagai berdiri sendiri EXE untuk pengiriman CD. Paket itu sebagai format ZIP untuk email cepat. Dan output berupa APP dapat digunakan di I-Phone, Tablet, I-Pad, dan lain-lain.

Salah satu materi perkuliahan yang dibuat ke dalam multimedia Flipbook adalah dasar teknik digital. Teknik digital adalah salah satu mata kuliah yang ada di Jurusan Pendidikan Teknik Elektro FPTK UPI yang merupakan mata kuliah wajib yang harus diambil oleh semua mahasiswa tingkat II. Kaitannya dengan proses perkuliahan, terkadang pendidik sebagai penyampai informasi kepada mahasiswa kurang bisa menciptakan suasana belajar yang menarik dan kondusif. Dengan pemakaian media pembelajaran ini juga diharapkan dapat membantu ketika dosen tidak bisa hadir untuk menyampaikan materi di dalam kelas seperti biasanya. Media pembelajaran ini dapat megurangi suasana yang statis dan dapat menciptakan proses pembelajaran yang efektif, menarik, interaktif dan menyenangkan. Kegunaan lain dari penggunaan alat bantu pembelajaran akan dapat menciptakan variasi belajar sehingga tidak menimbulkan kebosanan terhadap mahasiswa. Dengan alat bantu media pembelajaran ini diharapkan dapat membantu para mahasiswa untuk dapat memahami mengenai dasar-dasar teknik digital.

\section{METODE}

Penelitian ini dilakukan dengan menggunakan prosedur penelitian pengembangan dengan metode evaluatif. Penelitian dilakukan di Jurusan Pendidikan Teknik Elektro FPTK UPI. Subyek penelitian adalah mahasiswa tingkat tiga yang telah mengontrak atau menyelesaikan mata kuliah teknik digital di Jurusan Pendidikan Teknik Elektro FPTK UPI. Adapun pertimbangan 
pengambilan sampel adalah karena mahasiswa yang sudah mengontrak mata kuliah tersebut sudah mengetahui materi yang disampaikan sehingga tinggal bagaimana cara penyampaiannya dengan menggunakan media pembelajaran.

Tahap pertama pada penelitian diawali dengan pencarian silabus mengenai mata kuliah teknik digital di Jurusan Pendidikan Teknik Elektro FPTK UPI. Setelah menemukan silabus lalu peneliti menentukan kompetensi dasar apa saja yang dibutuhkan pada pengembangan media pembelajaran ini yaitu materi awal perkuliahan yang merupakan dasar dari teknik digital. Setelah kompetensi dasar ditentukan, selanjutnya peneliti mengumpulkan sumber-sumber bahan ajar atau literatur untuk pengembangan media pembelajaran ini.

Perancangan produk dalam penelitian ini di sesuaikan dengan kompetensi dasar dan dasar kompetensi yang harus dipenuhi dalam silabus pembelajaran teknik digital, untuk memenuhi hal tersebut maka penulis merancang media pembelajaran berbasis modul virtual dengan kriteria yaitu mudah dalam penggunaan dan desain yang cukup menarik serta menyajikan media pembelajaran yang menyenangkan.

Setelah menentukan materi apa saja yang akan dibahas berdasarkan silabus terkait, maka tahap selajutnya adalah mulai membuat atau mendesain modul. Desain modul yang telah dibuat dalam bentuk cetak kemudian diubah menjadi elektronik atau bentuk virtual dengan menggunakan bantuan perangkat lunak Kvisoft Flipbook Maker. Untuk menambah inovasi pada modul ini, peneliti mendesain soal evaluasi interaktif dengan menggunakan perangkat lunak Macromedia Flash 8 Professional yang tujuannya agar pengguna dapat mengetahui kemampuan memahami materi yang telah dibahas. Dengan berbantuan kedua perangkat lunak tersebut, peneliti berusaha membuat tampilan dari modul virtual ini lebih menarik sehingga pengguna akan mudah menggunakannya.

Setelah desain modul virtual selesai, tahap selanjutnya yaitu pengujian produk kepada tim ahli (expert). Pada tahapan ini, tim ahli berjumlah 6 orang yang terdiri dari 3 orang sebagai tim ahli di bidang studi atau isi materi pelajaran dan 3 orang di bidang media pembelajaran. Proses uji ahli isi materi dilakukan 
untuk menilai apakah materi yang disajikan pada modul ini sudah sesuai dengan silabus dan dapat digunakan dalam pembelajaran dasar teknik digital. Sedangkan proses uji ahli media pembelajaran dilakukan untuk menilai apakah media berbentuk virtual ini sudah layak digunakan untuk media pembelajaran. Setelah melakukan pengujian kepada tim ahli, maka tahapan selanjutnya adalah melakukan perbaikan atau revisi terhadap produk yang telah dibuat berdasarkan saran-saran atau masukan yang didapat. Perbaikan desain dilakukan untuk memperbaiki bagian-bagian produk yang masih kurang dan perlu pengembangan lagi sehingga dapat dihasilkan produk yang lebih baik lagi.

Rancangan produk yang sudah diperbaiki kemudian dilakukan ke tahap penelitian yang berupa pengujian secara terbatas kepada mahasiswa Jurusan Pendidikan Teknik Elektro FPTK UPI. Sampel yang digunakan pada penelitian ini yaitu berjumlah 32 orang dan merupakan mahasiswa tingkat tiga yang sudah mengontrak atau mengambil mata kuliah teknik digital. Pengujian ini dilakukan dengan tujuan untuk mendapatkan penilaian apakah modul virtual yang telah dibuat sudah cukup baik dan menarik serta efektif apabila digunakan sebagai alat bantu atau media dalam pembelajaran teknik digital.

Setelah mendapatkan data hasil penelitian, maka penelti melakukan analisa dan pembahasan terhadap data yang sudah didapatkan dari hasil penelitian sebelumnya. Setelah melakukan analisa, maka peneliti memasuki tahap akhir yaitu menarik kesimpulan. Instrumen yang digunakan sebagai pengumpulan data pada penelitian ini adalah catatan lapangan, angket (kuisioner) dan wawancara terstruktur. Catatan lapangan, berisikan informasi - informasi dalam proses pembuatan modul virtual sebagai media pembelajaran dasar teknik digital. Dalam penelitian ini, angket dan wawancara terstruktur berguna untuk mengetahui keadaan pembelajaran pada mata kuliah teknik digital, pendapat dari ahli dan mahasiswa mengenai kualitas modul virtual yang dibuat, baik dari segi materi dan tampilan modul virtualnya. Sebelum penyusunan angket dilakukan, maka terlebih dahulu dibuat kisi - kisi angket yang berisi variabel dan aspek yang akan dievaluasi.

Penelitian ini lebih menggali kelayakan media pada dua aspek : 
1. Aspek media, meliputi kejelasan petunjuk penggunaan program, keterbacaan teks, kualitas tampilan gambar, penggunaan gambar animasi yang menarik, komposisi warna, penggunaan suara musik sebagai ilustrasi.

2. Aspek instruksional seperti standar kompetensi yang akan dicapai, kemudahan memahami materi, keluasan dan kedalaman materi, kemudahan memahami kalimat yang digunakan, ketepatan urutan penyajian, kacukupan latihan, interaktifitas, ketepatan evaluasi, kejelasan umpan balik.

Teknik analisis data dilakukan setelah data dari seluruh responden atau sumber data lain terkumpul, antara lain:

1. Wawancara terstruktur,

Data yang diperoleh dari wawancara terstruktur ini berupa catatan lapangan tentang kondisi pembelajaran pada mata kuliah teknik digital. Kemudian data tersebut dijelaskan dalam bentuk deskriftif naratif.

2. Catatan Lapangan

Data yang berisi seluruh proses pembuatan modul virtual untuk dasar teknik digital dijelaskan dalam bentuk deskriptif naratif.

3. Kuesioner (Angket) tertutup,

Data yang diperoleh melalui kuisioner atau angket akan diuraikan secara deskriptif naratif.

\section{HASIL DAN PEMBAHASAN}

\section{Pembuatan Modul Virtual}

Silabus yang dipergunakan pada penelitian ini adalah silabus mata kuliah teknik digital di Jurusan Pendidikan Teknik Elektro FPTK UPI. Hal ini dikarenakan lokasi penelitiannya yaitu di Jurusan Pendidikan Teknik Elektro UPI. Kompetensi dasar pada penelitian ini dibatasi hanya 4 pokok bahasan, yaitu Sistem Bilangan, Gerbang Logika, Teknik Penyederhanaan, dan Flip-Flop. Keempat pokok bahasan tersebut merupakan dasar dari mata diklat teknik digital.

Setiap bahan ajar tentunya memiliki satu atau lebih sumber bahan ajar atau literaturnya. Dalam hal ini, sumber bahan ajar atau literatur yang dipergunakan cukup banyak dan tertera di setiap daftar pustaka pada setiap modul. Pada setiap 
modul, biasanya terdapat dua atau lebih literaturnya. Sumber bahan ajar yang digunakan pada pembuatan media pembelajaran ditampilkan pada tabel 1. Bahan ajar yang dikembangkan pada penilitian ini berupa modul virtual yang berisikan pokok bahasan mengenai dasar teknik digital setebal 131 halaman. Modul virtual ini berisikan empat modul dan setiap modul berisikan dua kegiatan belajar. Pada tabel 2 ditampilkan nama modul beserta kegiatan belajar dari setiap modul.

Tabel 1.Sumber bahan ajar yang digunakan

\begin{tabular}{cll}
\hline No. & \multicolumn{1}{c}{ Judul Buku/Referensi } & \multicolumn{1}{c}{ Penulis } \\
\hline 1 & Teknik Digital & KF. Ibrahim \\
2 & Prinsip-Prinsip dan Penerapan Digital & Malvino dkk \\
3 & Dasar Digital & Sigit Purnomo \\
4 & Dasar Digital & Tim Fakultas Teknik UNY \\
5 & Digital Electronics, 2nd ed & R.L Tokheim \\
6 & Elektronika Digital & Muhsin \\
7 & Modul Teknik Digital & Tim Yayasan Sandykara Putra \\
& & Telkom \\
8 & Aljabar Boole & Ismail Budiono \\
9 & Dasar-Dasar Rangkaian Logika Digital & Ismail Budiono \\
10 & Teknik Digital & W.N Widjanarka \\
11 & Teknik Digital, Mikroprosesor, & Lukas Willa \\
& Mikrokomputer & \\
12 & Electronics Principles, 3rd Editions & Malvino A.P, Ph.D \\
\hline
\end{tabular}

Tabel 2. Nama modul beserta kegiatan belajar

\begin{tabular}{cll}
\hline Urutan Modul & \multicolumn{1}{c}{ Nama Modul } & \multicolumn{1}{c}{ Kegiatan Belajar } \\
\hline \multirow{2}{*}{ Modul I } & Sistem Bilangan & Sistem Bilangan \\
& & Operasi Bilangan \\
Modul II & Gerbang Logika & Gerbang Logika Dasar \\
& & Gerbang Logika Kombinasi \\
Modul III & Teknik Penyederhanaan & Aljabar Boole \\
& & Peta Karnaugh \\
Modul IV & Flip-Flop dan Counter & Flip-Flop \\
& & Counter \\
\hline
\end{tabular}


Teks pada modul ditulis dengan menggunakan jenis huruf Times New Roman ukuran 12. Pemilihan format tersebut dikarenakan jenis dan ukuran huruf standar dan sering dipergunakan untuk pembuatan bahan ajar. Selain itu, sesuai dengan konsep modul dan adanya fasilitas zoom sehingga mampu memperbesar ukuran apabila kurang jelas. Untuk menambah daya tarik tampilan modul, dibuatlah cover atau halaman sampul untuk modul dasar teknik digital. Pembuatan cover ini menggunakan batuan perangkat lunak Adobe PhotoShop. Desain sampul menggunakan warna yang agak gelap dikarenakan pemberian warna pada background modul cukup gelap. Hal ini dimaksudkan agar ada keserasian warna antara cover dan background. Gambar pada cover juga didesain sejelas mungkin sesuai dengan mata diklat yang disajikan pada modul serta menggunakan bahasa yang sederhana. Pada gambar 1 ditampilkan desain cover modul virtual dasar teknik digital.

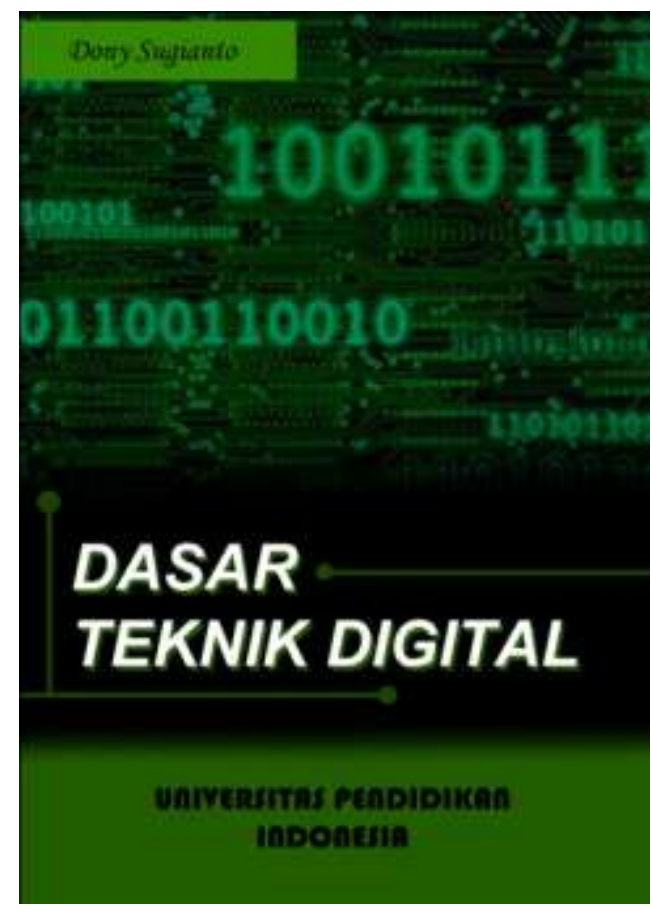

Gambar 1. Desain cover modul virtual

Setelah pembuatan cover, langkah selanjutnya adalah pembuatan soal evaluasi yang bersifat interaktif. Tujuannya adalah agar pengguna dapat mengetahui sejauh mana kemampuannya dalam memahami materi yang disampaikan. Pembuatan soal interaktif ini menggunakan bantuan perangkat lunak Macromedia Flash 8 Professional. Dalam proses pembuatan media pembelajaran modul virtual dasar teknik digital, peneliti memerlukan waktu yang cukup lama 
untuk mengerjakan dan menyelesaikannya. Hal ini dikarenakan proses atau tahapan-tahapan yang dilalui cukup banyak agar menghasilkan produk yang layak untuk digunakan sebagai media pembelajaran. Pada gambar 2 ditampilkan desain soal interaktif modul virtual dasar teknik digital.

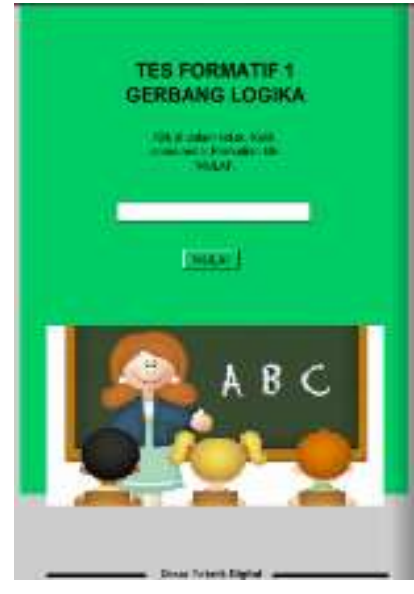

(a)

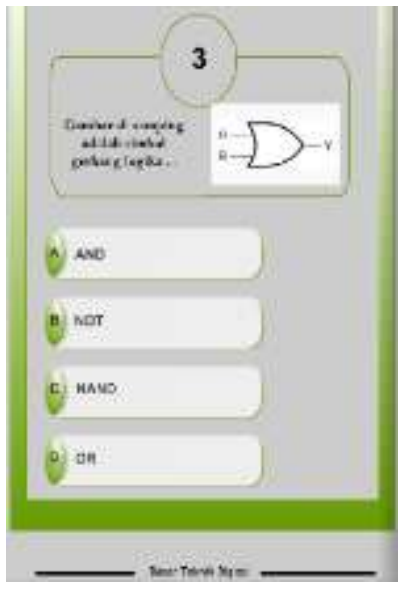

(b)

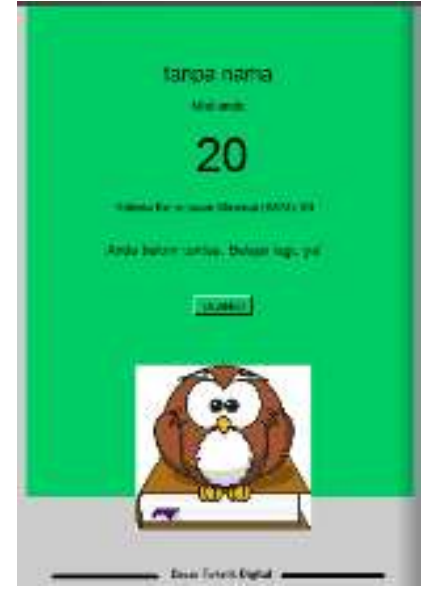

(c)

Gambar 2. Desain soal interaktif

(a) Tampilan awal soal interaktif, (b) tampilan pertanyaan dan pilihan jawaban (c) tampilan akhir soal interaktif

Gambar 2(a) memperlihatkan desain tampilan awal soal interaktif. Pada tampilan ini diberikan ilustrasi gambar seorang guru yang sedang mengajar dan papan tulisan yang bertuliskan $\mathrm{ABC}$. Hal ini menunjukkan agar pengguna akan menghadapi soal evaluasi materi tersebut. Sebelum mulai mencoba tes formatif, pengguna dipersilahkan untuk mengisi nama dan setelah itu klik tombol mulai. Gambar 2(b) menampilkan desain soal interaktif beserta pilihan jawabannya. Pengguna bisa langsung mengklik pada jawaban yang dianggap benar. Apabila setelah menjawab, maka akan langsung menuju soal berikutnya. Gambar 2(c) menampilkan desain akhir tampilan soal interaktif. Setelah menjawab semua soal, maka akan ditampilkan hasil dari jawaban berupa skor dan nama pengguna.

Produk final yang dihasilkan merupakan media pembelajaran berbentuk modul virtual dengan tambahan animasi agar tampilannya lebih menarik. Adapun pembahasan atau materi yang ditampilkan pada modul virtual ini yaitu mengenai dasar teknik digital. Produk ini dibuat dengan menggunakan bantuan software Kvisoft Flip Book Maker dan Macromedia Flash Professional 8. Media 
pembelajaran ini dikemas dalam format.exe dan .swf. Agar modul virtual ini dapat digunakan dan berjalan dengan baik pada sistem perangkat komputer, maka harus memiliki spesifikasi minimum sebagai berikut: (a) sistem operasi Windows 7/ $\mathrm{XP} / \mathrm{Vista} / 2000$. (b) prosesor minimal pentium III atau lebih, direkomendasikan pentium IV atau generasi setelahnya. (c) Memory RAM 512 MB, direkomendasikan IGB atau lebih tinggi. (d) Hard Disk $500 \mathrm{MB}$ atau lebih. (e) Flash Player 10.0 atau lebih.

Gambar 3 memperlihatkan desain modul virtual dasar teknik digital. Sesuai dengan cover, maka background yang digunakan sedikit gelap sehingga sesuai dengan cover. Pemberian tombol navigasi untuk mempermudah pengguna menggunakan modul virtual ini. Pada modul virtual ini juga diberikan musik atau suara agar pengguna tidak merasa bosan saat menggunakan media pembelajaran modul virtual ini.

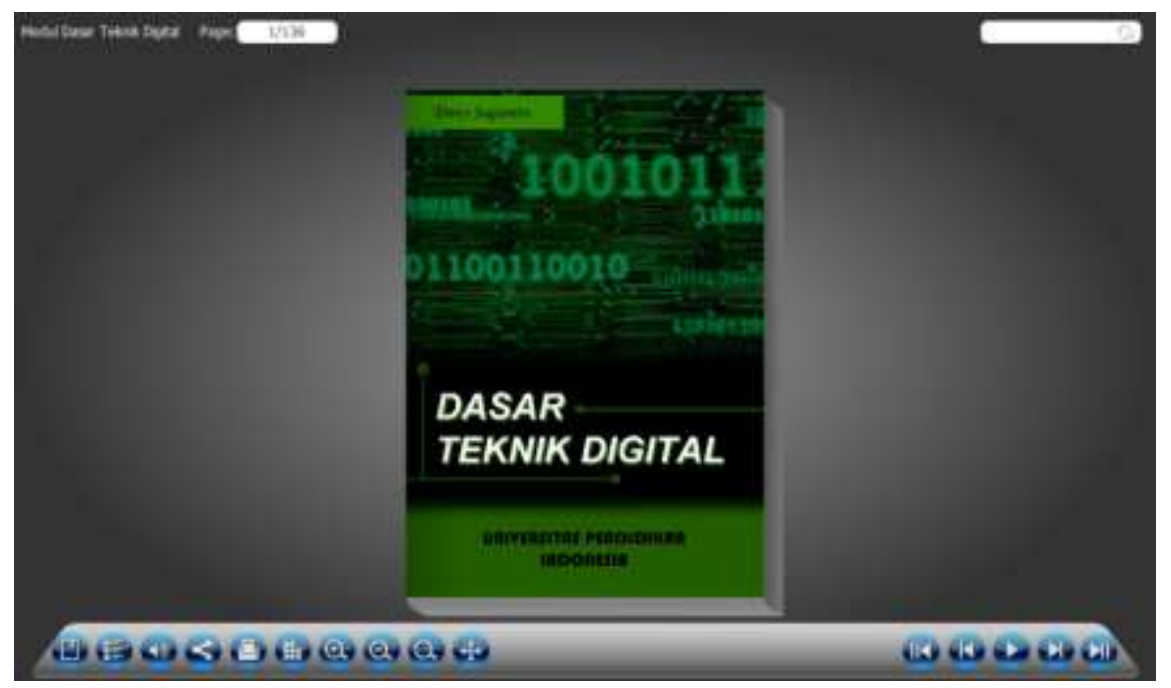

Gambar 3. Desain modul virtual dasar teknik digital

Sebagai pengembangan tahap awal, produk berupa Modul Virtual Dasar Teknik Digital harus melalui uji ahli isi materi. Ahli yang menganalisis isi materi pelajaran dan menilai produk ini berjumlah 3 orang yang terdiri dari 1 dosen dan 2 guru. Setiap ahli juga berhak memberikan saran atau masukan untuk menyempurnakan produk ini. Rancangan produk yang diserahkan kepada para ahli isi materi pelajaran adalah draft awal modul yang berbentuk hard copy. Hal ini dikarenakan sebelum dibuat ke dalam media pembelajaran, materi yang disajikan pun perlu diujikan terlebih dahulu. Berdasarkan hasil penilaian ahli isi 
materi pelajaran, maka persentase tingkat pencapaian produk ini sebesar 75,33\% . Dapat diinterpretasikan bahwa tingkat pencapaian yang didapat dari hasil ahli isi materi memiliki kualifikasi baik, sehingga tidak perlu revisi terhadap isi materi dari media pembelajaran ini.

Adapun saran yang diberikan oleh para ahli isi materi terhadap media pembelajaran ini antara lain: Modul dilengkapi dengan gambar-gambar agar mempermudah memahami materi yang dianggap sulit, soal pada evaluasi harus lebih bervariasi, penyampaian materi bisa disederhanakan dan penjelasan pada pokok bahasan gerbang logika dasar ditambah dengan penjelasan rangkaian elektronika.

Selain diuji ahli isi materi pelajaran, media pembelajaran ini juga harus diuju oleh ahli media pembelajarannya. Ahli yang menganalisis media pembelajaran dan menilai produk ini berjumlah 3 orang yang terdiri dari 1 orang dosen dan 2 orang guru. Setiap ahli juga berhak memberikan saran atau masukan untuk menyempurnakan produk ini. Rancangan produk yang diserahkan kepada para ahli media pembelajaran adalah media pembelajaran yang berbentuk animasi. Berdasarkan hasil penilaian ahli media pembelajaran, maka persentase tingkat pencapaian produk ini sebesar 78,67 \%. Dapat disimpulkan bahwa tingkat pencapaian yang didapat dari hasil ahli isi materi memiliki kualifikasi baik, sehingga tidak perlu revisi terhadap media pembelajaran ini.

Saran yang diberukan oleh para ahli media pembelajaran terhadap media pembelajara ini antara lain: warna background atau latar harus lebih halus dan cerah, konten dan template-nya harus disesuaikan dengan sasaran penelitian, akan lebih baik jika diinteraktifkan (jika diperlukan) dalam artian peserta belajar dapat menambah keingintahuannya dari interaksi dan pengguna. Sedangkan musik akan diusahakan dapat berganti-ganti dari suasana menyemangatkan hingga menenangkan pembaca.

\section{Implementasi Modul Virtual}

Pada tahap ini, peneliti menggambarkan hasil dari implementasi modul virtual dasar teknik digital yang melalui beberapa proses uji dan responden implementasi modul ini sebanyak 32 orang. Instrument yang digunakan dalam 
pengambilan data pada tahap ini yaitu berupa angket. Hasil pengolahan data memberikan gambaran sebagai berikut:

1. Kondisi pembelajaran dasar teknik digital saat ini kurang menarik dan cenderung monoton karena pendidik menggunakan metode ceramah dan tidak menggunakan media pembelajaran sehingga materi dianggap cukup sulit dan kurang dapat dipahami.

2. Responden mengalami kesulitan dalam memahami materi dikarenakan cara penyampaiannya kurang inovatif dan tidak adanya media bantu atau media pembelajaran untuk lebih memperjelas penyampaian materi. Cara yang mereka lakukan saat mengalami kesulitan dalam memahami materi yaitu dengan bertanya pada dosen dan teman yang lebih mengerti serta mencari media belajar yang mudah dipahami.

3. Media pembelajaran sangat diperlukan untuk setiap pembelajaran. Hal ini dikarenakan media dapat meningkatkan motivasi belajar dan proses belajar menjadi lebih menarik dan tidak monoton. Selain itu, dengan media pembelajaran dapat mempermudah dalam memahami materi yang disampaikan.

4. Dengan menggunakan media, kondisi pembelajaran akan lebih menarik dan tidak membosankan. Selain itu, materi yang disampaikan akan terasa mudah sekaligus dapat langsung memvisualisasikan materi yang disampaikan.

5. Modul virtual adalah modul yang dilengkapi dengan materi-materi sesuai dengan silabus yang ditampilkan melalui media elektronik serta berfungsi untuk mempermudah dalam proses pembelajaran sehingga pembelajaran menjadi lebih menarik dan tidak membosankan.

6. Modul virtual ini cukup baik untuk dijadikan sebagai alat bantu atau media dalam pembelajaran dan harus dikembangkan lebih lanjut karena dengan menggunakan media ini diharapkan para peserta didik dapat cepat memahami materi yang disampaikan dan dapat menambah motivasi untuk belajar.

7. Modul virtual ini dapat membantu peserta didik untuk memahami materi mengenai dasar teknik digital. Hal ini dikarenakan materinya yang cukup aplikatif dan lebih banyak animasi sehingga modul ini cukup efektif apabila digunakan sebagai media pembelajaran. 
8. Modul virtual ini layak digunakan sebagai media pembelajaran karena peserta didik merasa lebih mudah memahami materi dan dapat menghilangkan rasa kejenuhan pada saat pembelajaran. Modul virtual ini memiliki cakupan materi yang cukup dan sesuai dengan silabus. Tampilan modul virtual ini cukup menarik dan inovatif namun harus lebih disempurnakan kembali dikarenakan masih terdapat kekurangan.

Untuk menghasilkan produk media pembelajaran yang baik dibutuhkan waktu yang cukup lama dikarenakan tahapan atau proses yang cukup panjang. Sesudah produk dibuat, maka selanjutnya produk tersebut harus melalui beberapa tahap pengujian sehingga mendapat penilaian dan akhirnya dapat disempurnakan kembali. Adapun kendala dari pembuatan media ini adalah pembuatan modul berbentuk hard copy, pembuatan media pembelajarannya dengan ditambah interaktif, dan uji ahli dibidang isi materi dan media. Pembuatan storyboard menjadi pekerjaan yang sangat penting untuk dilakukan karena bertujuan untuk mempermudah peneliti untuk menentukan alur dari pembuatan media pembelajaran agar lebih terarah.

Penggunaan software gratis menjadi keunggulan produk modul virual ini, sehingga perancang terbebas dari keharusan membayar lisensi software. Modul virtual ini dapat digunakan sebagai alat bantu atau media pembelajaran pada mata diklat dasar teknik digital. Media pembelajaran ini bisa di share di media sosial, antara lain facebook, twitter, yahoo, dan google. Hal ini dimaksudkan agar para pengguna dapat mudah mengakses modul ini dimana dan kapan saja serta lebih banyak orang yang mengaksesnya.

Berdasarkan data yang diperoleh dari angket sebagian responden berpendapat positif mengenai media pembelajaran ini. Adapun pendapat responden mengenai media pembelajaran ini yakni sebesar $75 \%$ responden mengatakan modul virtual dasar teknik digital ini dapat membangkitkan motivasi, minat dan aktivitas belajar. Dan sebesar 78,125\% mengatakan bahwa penggunaan modul virtual dalam penyampain materi lebih mudah dipahami. Serta hasil dari wawancara terstruktur menyatakan bahwa modul virtual ini dapat membantu peserta didik untuk memahami materi mengenai dasar teknik digital. Hal ini 
dikarenakan materinya yang cukup aplikatif dan lebih banyak animasi sehingga modul ini cukup efektif apabila digunakan sebagai media pembelajaran.

Responden juga berpendapat mengenai kejelasan penyajian media dan materi dalam media pembelajaran ini. Sebanyak 78,125\% responden mengatakan desain sampul atau template yang digunakan pada modul virtual ini sangat menarik dan sesuai dengan sasaran penelitian. Sebanyak 90,625\% responden mengatakan bahwa materi yang disampaikan pada modul virtual ini sudah sesuai dengan tujuan dan silabus pembelajaran yang ada di jurusan pendidikan teknik elektro serta sebanyak $87,5 \%$ responden mengatakan bahwa isi materi yang terdapat pada modul virtual ini disampaikan secara terstruktur sehingga dapat terlihat saling ketertkaitan antara materi sebelum dan selanjutnya. Hal ini dapat memudahkan responden atau peserta didik dalam memahami.

Sebanyak 90,625\% responden mengatakan bahwa pengoperasian media pembelajaran modul virtual ini sangat mudah. Hal ini dikarenakan pemberian tombol menu dan navigasi pada modul virtual sudah tepat sehingga pengguna dapat langsung menggunakan tanpa tutorial terlebih dahulu serta bentuk menu pada modul virtual pada modul ini sudah sangat jelas dan mudah dipahami. Selain itu, kecepatan fungsi atau kinerja dari setiap tombol menu dan navigasivi pada modul ini sudah cukup cepat dan sesuai.

\section{KESIMPULAN}

Media pembelajaran berbentuk modul virtual dasar teknik digital sudah baik dan layak digunakan, dikarenakan proses pembuatan produk telah melalui tahapan perencanaan pembuatan media yang baku dan telah melalui pengujian para expert. Modul virtual ini mendapatkan penilaian positif dari dikarenakan materi pembelajaran menjadi sangat mudah dipahami oleh peserta didik. Selain itu, pengoperasian modul ini sangat mudah. Unsur musik dan animasi dinilai dapat meningkatkan motivasi, minat, dan aktivitas belajar para peserta didik.

\section{DAFTAR PUSTAKA}

Candiasa, I Made, 2004. "Pembelajaran Dengan Modul Berbasis Web". Jurnal Pendidikan dan Pengajaran IKIP Singaraja No.3 Th.XXXVII, Juli 2004. Jurusan Pendidikan Matematika Fakultas Pendidikan MIPA IKIP Singaraja. 
Gunadarma, Ananda. 2011. "Pengembangan Modul Elektronik Sebagai Sumber Belajar Untuk Mata Kuliah Multimedia Design”. Artikel Ilmiah Tugas Akhir. Fakultas Ilmu Pendidikan Universitas Negeri Jakarta

Gunawan, Dedi. 2010. “Modul Pembelajaran Interaktif Elektronika Dasar Untuk Program Keahlian Teknik Audio Video Smk Muhammadiyah 1 Sukoharjo Menggunakan Macromedia Flash 8". Jurnal KomuniTi, Vol. 2, No. 1, Juni 2010. Teknik Elektro Universitas Muhammadiyah Surakarta.

Munadi, Sudji. 2013. "Pengembangan Modul Pembelajaran Konstruktivistik Kontekstual Berbantuan Komputer Dalam Mata Diklat Pemesinan”. Artikel Ilmiah Tugas Akhir. Fakultas Teknik Universitas Negeri Yogyakarta.

Nazeri. 2013. "Penggunaan e-FlipBook dalam Topik Elektrik dan Elektronik: Inovasi dalam Pengajaran Reka Bentuk dan Teknologi PISMP RBT". Prosiding Seminar Penyelidikan IPG Zon Timur Vol 1, No 1 (2013).

Nurseto, Tejo. 2011. "Membuat Media Pembelajaran Yang Menarik". Jurnal Ekonomi \& Pendidikan Volume 8 Nomor 1. Fakultas Ekonomi Universitas Negeri Yogyakarta.

Ramdania, Diena Randa. 2013. "Penggunaan Media Flash Flip Book Dalam Pembelajaran Teknologi Informasi Dan Komunikasi Untuk Meningkatkan Hasil Belajar Siswa”. Artikel Ilmiah Tugas Akhir. Bandung. UPI

Salsabila, Rizky Prima Elisa Galuh. 2013. "Pengembangan Modul Elektronik Fisika Sebagai Media Instruksional Pokok Bahasan Hukum Newton Pada Pembelajaran Fisika Di SMA”. Jurnal Pembelajaran Fisika Issn 2301-9794 2013. Universitas Jember

Sudjana dan Rivai. (2005). Metoda Statistika. Bandung: PT. Tarsito 